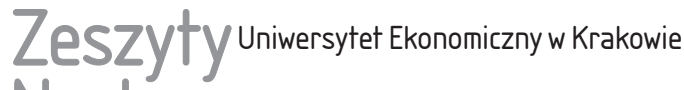 Naukowe
}



ISSN 1898-6447

Zesz. Nauk. UEK, 2016; 12 (960): 53-70 DOI: 10.15678/ZNUEK.2016.0960.1204

\author{
Sylwia Guzdek
}

\section{Pomoc publiczna dla przedsiębiorstw w Polsce w latach 2007-2013}

\section{Streszczenie}

Pomoc publiczna w Polsce stopniowo zaczyna nabierać charakteru pomocy stymulującej rozwój społeczno-gospodarczy, który jest jednym z podstawowych założeń odnowionej strategii lizbońskiej. Celem opracowania było przedstawienie skali i struktury udzielonej pomocy publicznej w Polsce w latach 2007-2013. Analiza danych w badanym okresie pozwoliła na sformułowanie następujących wniosków: beneficjentami ok. połowy wartości pomocy publicznej były duże przedsiębiorstwa, najczęściej stosowano instrumenty pomocy należące do grupy A1 (dotacje), najwyższą wartość miała pomoc regionalna. Po akcesji do Unii Europejskiej różnice między Polską a innymi krajami członkowskimi dotyczące przyznawania pomocy publicznej zaczęły się zacierać, m.in. za sprawą kontroli i nadzoru nad świadczeniem pomocy publicznej przez Komisję Europejską.

Słowa kluczowe: pomoc publiczna, przedsiębiorstwo, Unia Europejska, fundusze unijne. Klasyfikacja JEL: H2, H23.

\section{Wprowadzenie}

Pomoc publiczna w Polsce przyczynia się do rozwoju społeczno-gospodarczego. Przegląd stosowanych (dopuszczanych przez prawo krajowe i unijne) form pomocy publicznej wskazuje, że polityka w tym zakresie stanowi ważny element

Sylwia Guzdek, Uniwersytet Ekonomiczny w Krakowie, Wydział Ekonomii i Stosunków Międzynarodowych, Katedra Mikroekonomii, 31-510 Kraków, ul. Rakowicka 27, e-mail: guzdeks@uek.krakow.pl 
ingerencji współczesnego państwa w życie gospodarcze. Celem niniejszego artykułu jest charakterystyka i ocena udzielonej polskim przedsiębiorcom pomocy publicznej w latach 2007-2013.

\section{Istota pomocy publicznej}

Jedną z najważniejszych zasad wspólnego rynku jest zasada równej konkurencji, oznaczająca zagwarantowanie przedsiębiorcom porównywalnych warunków prowadzenia działalności gospodarczej. Zasada ta jest ograniczana przez udzielanie pomocy publicznej wybranym przedsiębiorcom lub towarom, chyba że udzielenie pomocy następuje w sposób zgodny z prawem [Krzemińska 2008, s. 8].

Pojęcie pomocy publicznej pojawiło się po raz pierwszy w układzie stowarzyszeniowym: „wszelka pomoc publiczna, która zniekształca lub grozi zniekształceniem konkurencji przez faworyzowanie niektórych przedsiębiorstw lub produkcji niektórych towarów jest niezgodna z właściwą realizacją Układu, jeżeli może mieć wpływ na handel między Polską a Wspólnotą" [Układ Europejski... 1991, art. 63 ust. 1 lit. iii]. Termin ,pomoc publiczna” został powtórzony w kolejnych ustawach o pomocy publicznej. Zgodnie z regulacjami unijnymi [Ustawa z dnia 30 kwietnia 2004...] określającymi zakres przedmiotowy jej obowiązywania: „Ustawa określa zasady postępowania w sprawach dotyczących pomocy państwa spełniającej przesłanki określone w art. 87 ust. 1 TWE, zwanej dalej pomocą publiczną" [Marquardt 2007, s. 37]. Zapis ten nie uległ zmianie także w Ustawie $\mathrm{z}$ dnia 8 stycznia 2010 r. o zmianie ustawy o postępowaniu w sprawach dotyczących pomocy publicznej.

Niektórzy z autorów podważają celowość formułowania definicji pomocy publicznej w rozumieniu Traktatu jako niepotrzebną i z góry skazaną na niepowodzenie, wychodząc z założenia, że zupełnie wystarczające jest rozstrzyganie ad casum o dopuszczalności udzielania określonej pomocy ${ }^{1}$ [Marquardt 2007, s. 37]. U. Krzemińska [2008, s. 8] podkreśla, że pojęcie pomocy nie zostało zdefiniowane w prawie wspólnotowym ani w prawie polskim. Europejski Trybunał Sprawiedliwości w swoich orzeczeniach nie zawarł definicji pomocy publicznej, stwierdził jedynie, że to pojęcie powinno być interpretowane szeroko i że jest szersze od pojęcia dotacji. Wielu autorów podejmuje jednak próby skonstruowania definicji pomocy publicznej. Klasyfikację takich definicji przedstawia P. Marquardt [2007, s. 37], dzieląc je na trzy grupy, które koncentrują się na: 1) korzyściach odno-

${ }^{1}$ W podobnym duchu wypowiedział się Europejski Trybunał Sprawiedliwości (ETS) - orzeczenie ETS z 10 lipca 1986 r. w sprawie 234/84: Belgia v. Komisja i opinia AG Lenza z dnia 16 kwietnia 1986 r. (s. 2263) [Marquardt 2007, s. 37]. 
szonych przez beneficjentów pomocy, 2) wydatkach ponoszonych przez państwo, 3) zamierzonych celach stawianych danej pomocy przez państwa jej udzielające.

Najogólniej rzecz biorąc, przez pomoc publiczną należałoby rozumieć określone korzyści, jakie przypadają określonemu przedsiębiorcy bądź też grupie przedsiębiorców, których nie mogliby uzyskać w toku normalnej działalności gospodarczej, a której szeroko rozumiane państwo nie udzieliłoby, gdyby działało na takich samych zasadach jak zwykły inwestor (tzw. test inwestora prywatnego). Pomoc nie musi przyjmować postaci aktywnego działania, może polegać również na zaniechaniu. Może być udzielana za pomocą instrumentów prawa publicznego (dotacje, subwencje, zwolnienia podatkowe) bądź też instrumentów prawa cywilnego (gwarancje, preferencyjne oprocentowanie, dostarczenie towarów lub usług na preferencyjnych warunkach). Podstawowym kryterium uznania danego działania za pomoc jest jednak efekt, jaki wywołuje z punktu widzenia potencjalnego beneficjenta odnoszącego ściśle wymierną korzyść, rozumianą jako przyznanie określonego prawa bądź też zwolnienie z ciążącego nań obowiązku [Marquardt 2007, s. 36].

Zgodnie z art. 87 Traktatu ustanawiającego Wspólnotę Europejską wszelka pomoc przyznawana przez państwo członkowskie lub przy użyciu zasobów państwowych w jakiejkolwiek formie, która zakłóca lub grozi zakłóceniem konkurencji przez sprzyjanie niektórym przedsiębiorstwom lub produkcji niektórych towarów, jest niezgodna ze wspólnym rynkiem w zakresie, w jakim wpływa na wymianę handlową między państwami członkowskimi. Udzielanie pomocy może zatem naruszać konkurencję na rynku i dlatego jest poddane kontroli. Na uznanie danego świadczenia za pomoc nie ma wpływu forma, w jakiej zostało udzielone ${ }^{2}$.

Cztery cechy decydują o uznaniu pomocy za pomoc publiczną: pomoc musi być udzielona ze środków publicznych lub przez państwo, musi prowadzić do

2 Traktat z Lizbony, zmieniający Traktat o Unii Europejskiej i Traktat ustanawiający Wspólnotę Europejską, sporządzony w Lizbonie 13 grudnia 2007 r., wszedł w życie 1 grudnia 2009 r. W dziedzinie pomocy publicznej wprowadził on nieznaczne zmiany. Mają one częściowo charakter ogólny (zmiana nazewnictwa i renumeracja artykułów), a często specyficzny (zmiany o charakterze merytorycznym w art. 87-89 TWE - podstawowych przepisach traktatowych w dziedzinie pomocy publicznej). Od 1 stycznia 2007 r. nastąpiły zasadnicze zmiany w prawie wspólnotowym w zakresie pomocy publicznej. Zmieniły się przepisy dotyczące pomocy regionalnej oraz pomocy de minimis. Pojawił się nowy rodzaj wyłączenia grupowego, tzw. przejrzysta regionalna pomoc inwestycyjna. Głównym celem nowelizacji przepisów krajowych było uregulowanie kwestii notyfikacji, monitorowania i sprawozdawczości pomocy publicznej w rolnictwie i rybołówstwie. Dla tych sektorów organem monitorującym pomoc jest minister właściwy ds. rolnictwa. Natomiast 25 kwietnia 2008 r. Sejm RP uchwalił kolejną nowelizację Ustawy z dnia 30 kwietnia 2004 r. o postępowaniu w sprawach dotyczących pomocy publicznej. Celem nowelizacji było dostosowanie ustawy do przepisów wspólnotowych, w tym przede wszystkim pomocy de minimis [Kierunki udzielania... 2008, Raport o pomocy... 2011]. Zob. również: http://www.bip.krakow.pl/?bip_id=1\&mmi=503, http://www. mr.gov.pl, http://www.uokik.gov.pl/pomoc_publiczna_2.php\#faq330 (data dostępu: 10.05.2016). 
uprzywilejowania niektórych przedsiębiorców lub produkcji niektórych towarów, przynosząc wymierne korzyści dla beneficjentów, musi zakłócać konkurencję lub grozić jej zakłóceniem oraz musi wpływać na wymianę handlową między państwami członkowskimi. Zakłócenie konkurencji polega na stworzeniu takiej sytuacji, w której pozycja podmiotu uzyskującego wsparcie jest lepsza niż jego konkurentów, zarówno w różnych krajach członkowskich, jak i w jednym kraju członkowskim. Przyjmuje się, że aby uznać dane działanie za pomoc publiczną, wymienione cechy muszą wystąpić łącznie. Niezależnie od szczegółowej podstawy prawnej, na jakiej pomoc publiczna jest udzielana, aby uzyskać akceptację Komisji, powinna spełniać przede wszystkim kryteria: przejrzystości, proporcjonalności, subsydiarności oraz spójności.

Za niedopuszczalną - w świetle art. 87 ust. 1 TWE - należy uznać pomoc publiczną, która wywiera wpływ na wymianę handlową (kapitału, towarów, usług) pomiędzy państwami członkowskimi [Krzemińska 2008, s. 8-10]. Kryteriami przesądzającymi o niedopuszczalności udzielania pomocy są najczęściej: defensywny charakter pomocy (wykorzystanie pomocy jedynie jako celu do zachowania status quo), przeznaczenie pomocy na zwiększenie produkcji, naruszenie zasady proporcjonalności (zwłaszcza przez przekroczenie dopuszczalnych pułapów intensywności) oraz naruszenie zasady przejrzystości przez uchybienia proceduralne (brak notyfikacji bądź niedochowanie obowiązujących terminów na przekazanie informacji Komisji) ${ }^{3}$.

Pomoc publiczna może być udzielana w szczególności w formie [Raport o pomocy... 2011, s. 3-4] $]^{4}$ :

- dotacji oraz ulg i zwolnień podatkowych,

- dokapitalizowania przedsiębiorców na warunkach korzystniejszych od oferowanych na rynku,

${ }^{3}$ Można stwierdzić, że Komisja, oceniając dopuszczalność proponowanej pomocy publicznej, rozważa z jednej strony jej możliwe negatywne skutki uboczne (w postaci zakłócenia handlu lub konkurencji), z drugiej - możliwe pozytywne efekty jej udzielenia. Efekty pozytywne rozpatrywane są pod kątem: 1) precyzyjności celu, jakiemu ma służyć dana pomoc, 2) rozstrzygnięcia, czy pomoc publiczna jest właściwym środkiem do rozwiązania określonego problemu, 3) ustalenia, czy udzielenie proponowanej pomocy będzie stymulatorem pożądanych zmian. Efekty negatywne rozpatrywane są natomiast pod kątem: 1) procedury wyboru beneficjentów, 2) warunków przyznania pomocy, 3) cech rynku, na jakim działa beneficjent, oraz samego beneficjenta, 4) wysokości i rodzaju pomocy [Marquardt 2007, s. 98-99].

${ }^{4}$ Zgodnie z wytycznymi Komisji Europejskiej wyróżniono cztery grupy oznaczone literami A, B, C i D. Kolejnym literom przypisano cyfrę 1 lub 2, w zależności od źródła pochodzenia środków pomocowych (odpowiednio z budżetu lub kosztem uszczuplenia wpływów budżetowych). Z uwagi na brak możliwości przyporządkowania niektórych formy pomocy do jednej z ww. grup stworzono grupę oznaczoną literą E. 
- pożyczek lub kredytów udzielanych przedsiębiorcom na warunkach korzystniejszych od oferowanych im na rynku,

- poręczeń i gwarancji udzielanych za zobowiązania przedsiębiorców na warunkach korzystniejszych od oferowanych na rynku,

- zaniechania poboru podatku, odroczenia terminu zapłaty, rozłożenia na raty podatku lub zaległości podatkowej wraz z odsetkami za zwłokę oraz umorzenia zaległości podatkowej bądź odsetek za zwłokę lub opłaty prolongacyjnej,

- umorzenia bądź zaniechania ustalania lub poboru należnych od przedsiębiorcy świadczeń pieniężnych, stanowiących środki publiczne w rozumieniu przepisów ustawy o finansach publicznych, innych niż podatki, albo odraczania lub rozkładania na raty płatności takich świadczeń,

- zbycia lub oddania do korzystania mienia będącego własnością Skarbu Państwa lub jednostek samorządu terytorialnego i ich związków na warunkach korzystniejszych od oferowanych na rynku.

\section{Rodzaje unijnej pomocy publicznej}

Pomoc publiczna ${ }^{5}$ może występować jako pomoc indywidualna - to każda pomoc, która nie jest przyznawana na podstawie programu pomocowego (aktu normatywnego), oraz pomoc przyznawana na podstawie programu pomocowego i podlegająca procedurze notyfikacji (obowiązkowi zgłoszenia) do Komisji Europejskiej lub jako pomoc w ramach programu pomocowego - udzielana na podstawie aktu prawnego określającego warunki udzielenia pomocy indywidualnej bez konieczności jej notyfikowania ${ }^{6}$.

${ }_{5}$ Pomoc publiczna, przyznana w innej formie niż dotacja, przeliczana jest na ekwiwalent dotacji brutto. Przy obliczaniu pomocy wypłacanej w kilku ratach zastosowanie znajdują rynkowe stopy procentowe obowiązujące $\mathrm{w}$ chwili przyznawania pomocy. Za rynkowe stopy procentowe uznaje się stopy referencyjne. Zgodnie z Komunikatem Komisji w sprawie zmiany metody ustalania stóp referencyjnych i dyskontowych dla każdego państwa członkowskiego publikowana jest tzw. stopa bazowa, do której dodaje się odpowiednią marżę wyrażoną w punktach bazowych ustaloną indywidualnie dla przedsiębiorcy przez organ udzielający pomocy. Marżę ustala się na podstawie dwóch kryteriów: tzw. ratingu (uwzględniającego sytuację ekonomiczno-finansową przedsiębiorcy, w tym w szczególności jego zdolność kredytową i wypłacalność) oraz poziomu zabezpieczeń związanych $\mathrm{z}$ udzieleniem pomocy w formie kredytowej. Wartość pomocy publicznej wyrażana jest w euro według kursu średniego walut obcych, ogłoszonego przez Narodowy Bank Polski, obowiązującego w dniu udzielenia pomocy.

${ }^{6}$ Szczególną kategorię pomocy stanowi pomoc de minimis, której udzielenie ze względu na jej znikomą wartość nie skutkuje zakłóceniem konkurencji w wymiarze wspólnotowym. Pomoc de minimis nie spełnia wszystkich kryteriów określonych w art. 107 ust. 1 TFUE i może być stosowana pod warunkiem zapewnienia właściwych warunków jej udzielania i monitorowania 
Pomoc publiczna najczęściej występuje jako pomoc regionalna, udzielana w zakresie wynikającym z mapy pomocy regionalnej, oraz jako pomoc horyzontalna, przeznaczona na badania i rozwój, ochronę środowiska, małe i średnie przedsiębiorstwa, zatrudnienie, szkolenia, pomoc na restrukturyzację, pomoc doraźna. W ramach pomocy horyzontalnej wyróżniamy pomoc udzielaną na podstawie tzw. wyłączeń grupowych. Pomoc ta, bez względu na to, czy stanowi pomoc indywidualną, czy pomoc udzielaną na podstawie programu pomocowego, zwolniona jest z obowiązku notyfikacji $\mathrm{KE}^{7}$.

Możliwość udzielenia pomocy regionalnej wynika z art. 107 ust. 3a Traktatu o funkcjonowaniu Unii Europejskiej. Jest udzielana w celu wyrównywania różnic w rozwoju poszczególnych regionów w ramach całej Unii ${ }^{8}$.

Udzielenie pomocy horyzontalnej nie jest uzależnione od regionu, w którym beneficjent pomocy prowadzi działalność. Jest ona nastawiona na realizację pewnych określonych celów. Pomoc udzielana jest na: restrukturyzację, ratowanie, rozwój małych i średnich przedsiębiorstw, zatrudnienie, prace badawczo-rozwojowe, szkolenia, inwestycje związane z ochroną środowiska.

W ramach pomocy publicznej wyróżnić można również pomoc sektorową. Jest to pomoc udzielana przedsiębiorcom prowadzącym działalność w określonych sektorach, dla których obowiązują odrębne zasady przyznawania wsparcia. Pomoc dotyczy sektorów wrażliwych, takich jak: budownictwo okrętowe, żegluga morska, górnictwo węgla, hutnictwo żelaza i stali, przemysł włókien sztucznych oraz przemysł motoryzacyjny. Do pomocy sektorowej zaliczamy także pomoc przyznawaną na działalność rolniczą i rybołówstwo.

(http://www.bip.krakow.pl/?bip_id=1\&mmi=503, http://www.uokik.gov.pl/pomoc_publiczna_2. php\#faq330, data dostępu: 10.05.2016).

7 Od 29 sierpnia 2008 r. obowiązuje Rozporządzenie Komisji (WE) nr 800/2008 z dnia 6 sierpnia 2008 r. uznające niektóre rodzaje pomocy za zgodne ze wspólnym rynkiem w zastosowaniu art. 87 i 88 Traktatu (ogólne rozporządzenie w sprawie wyłączeń blokowych).

${ }^{8}$ Od 1 stycznia 2007 r. pomoc regionalna była udzielana na podstawie dokumentu: Wytyczne w sprawie krajowej pomocy regionalnej na lata 2007-2013. Pomoc publiczna jest dopuszczalna tylko w regionach, w których poziom PKB na mieszkańca wynosi poniżej 75\% średniej unijnej. Warunek ten spełnia cały obszar Polski i tym samym kwalifikuje się do pomocy regionalnej. Pomoc regionalna może być udzielana w zakresie wynikającym z mapy pomocy regionalnej. W latach 2007-2013 obszary, na których dopuszczalne było udzielanie pomocy regionalnej na terenie Polski, określało Rozporządzenie Rady Ministrów z dnia 13 października 2006 r. w sprawie ustalenia mapy pomocy regionalnej. 


\section{Przedsiębiorstwa jako główni beneficjenci horyzontalnej pomocy publicznej}

\subsection{Uwagi ogólne}

W analizowanym okresie beneficjentami ok. połowy wartości pomocy publicznej były duże przedsiębiorstwa. W 2013 r. udział ten zmniejszył się do $39,3 \%$ wartości udzielonej pomocy publicznej. W przypadku średnich przedsiębiorstw udział ten wynosił $26,2 \%$, w przypadku małych - 20,7\%, a w przypadku mikroprzedsiębiorstw - 13,8\% [Raport o pomocy... 2014, s. 40]. W 2014 r. wskaźnik dla dużych przedsiębiorstw wzrósł do 62\% [Raport o pomocy... 2015, s. 42]. Należy stwierdzić, że pomoc udzielana dużym przedsiębiorcom, mającym silną pozycję konkurencyjną na rynku, stanowi potencjalnie większe ryzyko naruszenia konkurencji niż pomoc udzielana podmiotom małym i średnim, a zatem przedstawionej wyżej struktury nie można uznać za pożądaną.

Udział wartości pomocy otrzymanej w 2013 r. przez beneficjentów posiadających określony status prawny w ogólnej wartości udzielonej pomocy kształtował się podobnie jak w latach poprzednich. Zdecydowanie największe wsparcie uzyskały przedsiębiorstwa prywatne (ok. 84\% ogólnej wartości pomocy), co jest skutkiem przede wszystkim wzrostu pomocy udzielonej tej kategorii beneficjentom przez prezesa Agencji Rozwoju Przedsiębiorczości w ramach Programu Operacyjnego Innowacyjna Gospodarka i marszałków województw w ramach regionalnych programów operacyjnych. W 2013 r. odnotowano wyraźny spadek udziału pomocy udzielonej spółkom Skarbu Państwa, jednostkom samorządu terytorialnego, państwowym lub komunalnym jednostkom organizacyjnym (z 15,6\% do 7,9\%), głównie z powodu zmniejszenia wartości pomocy udzielonej przedsiębiorcom działającym w sektorze energetyki przez prezesa Urzędu Regulacji Energetyki (URE) z przeznaczeniem na rekompensatę za rozwiązanie umów sprzedaży mocy i energii elektrycznej [Raport o pomocy... 2014, s. 44-45]. W omawianym okresie, przyjmując założenie większej efektywności wykorzystania środków przez podmioty prywatne, należy pozytywnie ocenić fakt, że udział przedsiębiorstw prywatnych wśród beneficjentów pomocy publicznej jest większy i utrzymuje się na wysokim poziomie [Raport o pomocy... 2011, s. 31-32].

\subsection{Skala i struktura pomocy publicznej w latach 2007-2013}

Ogólna wartość pomocy publicznej udzielonej przedsiębiorcom w $2013 \mathrm{r}$. wyniosła 22 116,9 mln PLN [Raport o pomocy... 2015, s. 17] (tabela 1). Warto dodać, że w 2014 r. zaobserwowano wzrost wartości pomocy w porównaniu $\mathrm{z}$ rokiem poprzednim o prawie $15 \%$, co wynika przede wszystkim z rozpoczęcia 
przez ministra środowiska udzielania spółkom energetycznym pomocy w formie bezpłatnych uprawnień do emisji gazów cieplarnianych (3,9 mld PLN) oraz ze wzrostu wartości pomocy udzielonej w sektorze transportu o 1,9 mld PLN spowodowanego wzrostem wartości rekompensaty z tytułu realizacji zadań świadczonych w ogólnym interesie gospodarczym udzielanej spółkom komunikacji miejskiej (o 2,3 mld PLN) [Raport o pomocy... 2015, s. 72].

Tabela 1. Pomoc publiczna udzielona w latach 2007-2013

\begin{tabular}{|l|c|c|c|c|c|c|c|}
\hline \multicolumn{1}{|c|}{ Wyszczególnienie } & 2007 & 2008 & $2009^{\mathrm{a}}$ & $2010^{\mathrm{a}}$ & $2011^{\mathrm{b}}$ & $2012^{\mathrm{b}}$ & $2013^{\mathrm{b}}$ \\
\hline $\begin{array}{l}\text { Ogólna wartość udzielo- } \\
\text { nej pomocy (w mln PLN) }\end{array}$ & 6549,5 & 14383,1 & 19173,4 & 24087,3 & 21462,5 & 21795,6 & 22116,9 \\
\hline $\begin{array}{l}\text { Wartość pomocy z wyłą- } \\
\text { czeniem transportu } \\
\text { (w mln PLN) }\end{array}$ & 4847,2 & 11521,9 & 16087,2 & 21235,5 & 17955,1 & 18054,9 & 18154,6 \\
\hline $\begin{array}{l}\text { Udział wartości pomocy } \\
\text { w PKB (w \%) }\end{array}$ & 0,6 & 1,13 & 1,43 & 1,7 & 1,4 & 1,37 & 1,35 \\
\hline $\begin{array}{l}\text { Udział wartości pomocy } \\
\text { w PKB z wyłączeniem } \\
\text { transportu (w \%) }\end{array}$ & 0,4 & 0,91 & 1,2 & 1,5 & 1,17 & 1,13 & 1,11 \\
\hline
\end{tabular}

Uwaga: przedstawiane w raportach zaokrąglone sumy poszczególnych kwot są obliczane z uwzględnieniem ich pełnego rozwinięcia (przed zaokrągleniem) i nie zawsze są równe sumie poszczególnych kwot zaokrąglonych.

${ }^{a}$ Kwoty za lata 2008-2010 uwzględniają środki finansowe pochodzące z funduszy unijnych finansujące lub współfinansujące pomoc. Kwoty za lata wcześniejsze uwzględniają tylko środki krajowe. Zgodnie z informacjami zamieszczonymi w Raporcie o pomocy... [2011], do ogólnej wartości pomocy nie wliczono pomocy udzielonej w formie wynagrodzeń przedsiębiorstwu Gdańsk Transport Company SA z tytułu budowy i eksploatacji autostrady A1 na odcinku Gdańsk-Toruń z uwagi na brak określenia w decyzji Komisji Europejskiej z dnia 13 maja 2009 r. w sprawie pomocy nr N 151/2009 i N 152/2009 - Pomoc na budowę i eksploatację autostrady A1 (odcinek Toruń-Gdańsk), jaka część ww. wynagrodzeń stanowi pomoc publiczną.

b Kwoty za lata 2011-2013 nie uwzględniają pomocy udzielonej w formie wynagrodzeń przedsiębiorstwu Gdańsk Transport Company SA z tytułu budowy i eksploatacji autostrady A1 na odcinku Gdańsk-Toruń, przedsiębiorstwu Autostrada Wielkopolska II SA z tytułu budowy i eksploatacji autostrady A2 na odcinku Świecko-Nowy Tomyśl z uwagi na brak określenia, jaka część ww. wynagrodzeń stanowi pomoc publiczną w decyzji Komisji Europejskiej z dnia 13 maja 2009 r. w sprawie pomocy nr N 151/2009 i N 152/2009 oraz w decyzji z dnia 2 grudnia 2009 r. w sprawie pomocy nr N 462/2009. Powyższe kwoty nie uwzględniają także rekompensaty przekazanej Autostradzie Wielkopolskiej SA na podstawie Ustawy z dnia 28 lipca 2005 r. o zmianie ustawy o autostradach płatnych oraz o Krajowym Funduszu Drogowym oraz ustawy o transporcie drogowym z uwagi na toczące się postępowanie mające na celu ocenę, czy przedmiotowa rekompensata stanowi pomoc publiczną.

Źródło: opracowanie własne na podstawie: [Raport o pomocy... 2011, s. 11; Raport o pomocy... 2014, s. 16; Raport o pomocy... 2015, s. 17].

Pomoc publiczna udzielona przedsiębiorcom w 2013 r. stanowiła 1,35\% PKB, a zatem jej poziom był porównywalny do odnotowanego w $2012 \mathrm{r}$. W $2014 \mathrm{r}$. pomoc publiczna stanowiła 1,46\% (25 262,8 $\mathrm{mln}$ PLN). Wartość pomocy udzielonej w omawianym okresie uwzględnia środki pomocowe pochodzące $\mathrm{z}$ funduszy europejskich. W 2013 r. wartość udzielonej pomocy, z wyłączeniem pomocy w transporcie (3962,4 mln PLN), wyniosła 18 154,6 mln PLN, co stanowiło 1,11\% 
PKB [Raport o pomocy... 2011, s. 11; Raport o pomocy... 2014, s. 16; Raport o pomocy... 2015, s. 17].

W 2013 r., podobnie jak w latach poprzednich, najczęściej stosowano instrumenty pomocy należące do grupy A1 (dotacje); stanowiły one 86,3\% ogólnej wartości pomocy [Raport o pomocy... 2015, s. 22]. Formy pomocy publicznej dla polskich przedsiębiorstw przedstawiono w tabeli 2 .

Tak jak w latach poprzednich w 2013 r. zdecydowanie więcej pomocy udzielono w formie bezpośrednich wydatków $(86,6 \%)$ niż w formie uszczupleń wpływów do budżetu $(13,4 \%)$ [Raport o pomocy... 2015, s. 23]. Sposoby finansowania pomocy państwa w Polsce przedstawiono w tabeli 3.

W latach 2007-2013 zdecydowanie więcej pomocy udzielono w formie bezpośrednich wydatków (ok. 80\%) niż w formie uszczupleń wpływów do budżetu (20\%). Utrzymuje się przewaga pomocy udzielanej w tzw. aktywnych formach nad pomocą udzielaną w formach pasywnych. Na wzrost różnicy między udziałami ww. form pomocy w ogólnej wartości udzielonej pomocy wpłynął wzrost pomocy udzielanej w formie dotacji (jej wartość bezwzględna utrzymywała się na niezmienionym poziomie ponad 15 mld PLN) oraz stopniowy spadek udziału pomocy w formie ulg (chociaż w 2014 r. zaobserwowano wzrost pomocy udzielonej w formie zwolnień i ulg podatkowych [Raport o pomocy... 2011, s. 15; Raport o pomocy... 2014, s. 22; Raport o pomocy... 2015, s. 23].

Strukturę udzielonej pomocy publicznej w latach 2007-2013 według jej przeznaczenia przedstawiono $\mathrm{w}$ tabeli 4. Pomoc regionalna udzielona w $2013 \mathrm{r}$. (9457,1 mln PLN) stanowiła ponad połowę ogólnej wartości udzielonej pomocy i była najwyższa $\mathrm{w}$ analizowanym okresie. Zdecydował o tym przede wszystkim wzrost wartości pomocy udzielanej na tworzenie nowych inwestycji, głównie finansowanej z regionalnych programów operacyjnych i Programu Operacyjnego Innowacyjna Gospodarka [Raport o pomocy... 2014, s. 24]. Wartość pomocy regionalnej udzielonej w 2014 r. (8190,9 mln PLN) stanowiła ponad 40\% ogólnej wartości udzielonej pomocy i zmniejszyła się o ponad $10 \%$ w porównaniu z rokiem poprzednim [Raport o pomocy... 2015, s. 26]. Pomoc horyzontalna udzielona w 2013 r. w wysokości 4997,9 mln PLN stanowiła ponad 30\% ogólnej wartości pomocy udzielonej w tym roku. W porównaniu z latami poprzednimi wartość ta zmniejszyła się (głównie ze względu na spadek wartości pomocy na ratowanie przedsiębiorstw oraz na badania i rozwój), a jej udział w ogólnej wartości udzielonej pomocy publicznej był najniższy w całym analizowanym okresie. Jeśli chodzi o przeznaczenie pomocy horyzontalnej, w latach 2007-2013 odnotowano największy wzrost pomocy na zatrudnienie [Raport o pomocy... 2014, s. 24-25]. W 2014 r. udzielono najwięcej pomocy horyzontalnej (8574,6 mln PLN); stanowiła ona ponad $40 \%$ ogólnej wartości pomocy udzielonej w danym roku [Raport o pomocy... 2015, s. 25]. 


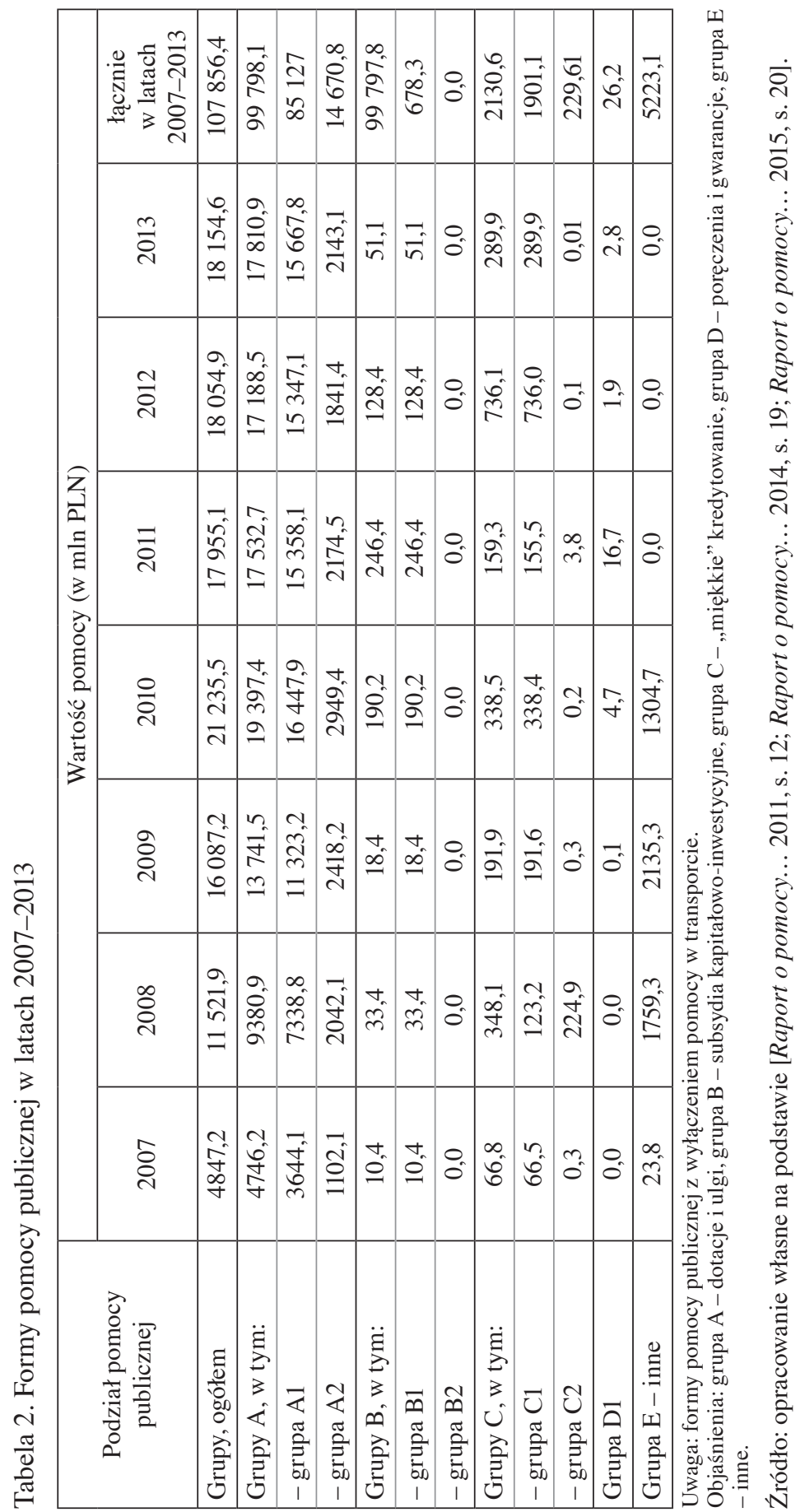


Tabela 3. Sposób finansowania pomocy państwa w Polsce (w \%)

\begin{tabular}{|c|c|c|}
\hline Rok & $\begin{array}{c}\text { Bezpośrednie wydatki } \\
\text { (głównie dotacje) }\end{array}$ & $\begin{array}{c}\text { Pozostałe formy } \\
\text { (głównie uszczuplenia wpływów } \\
\text { do budżetu) }\end{array}$ \\
\hline 2013 & 86,6 & 13,4 \\
\hline 2012 & 85,7 & 14,3 \\
\hline 2011 & 86,9 & 13,1 \\
\hline 2010 & 78,4 & 21,6 \\
\hline 2009 & 70,5 & 29,5 \\
\hline 2008 & 64,0 & 36,0 \\
\hline 2007 & 75,4 & 24,6 \\
\hline
\end{tabular}

Uwaga: do bezpośrednich wydatków zaliczono pomoc udzieloną w formie dotacji (grupa A1) oraz wniesienia kapitału do spółki (grupa B1).

Źródło: opracowanie własne na podstawie [Raport o pomocy... 2011, s. 15; Raport o pomocy... 2014, s. 22; Raport o pomocy... 2015, s. 23].

W analizowanym okresie zaobserwowano znaczy spadek pomocy sektorowej w 2012 r. - wyniosła ona 1865,4 mln PLN. W 2013 r. wartość ta wzrosła do 2946 mln PLN. Wartość pomocy sektorowej udzielonej w 2014 r. znacząco spadła w porównaniu z rokiem poprzednim (o 1516,7 mln PLN). Największy spadek wartości pomocy sektorowej (o 685,2 mln PLN) odnotowano w sektorze energetyki [Raport o pomocy... 2014, s. 24-25 i 64]. Od 2010 r. udzielana jest pomoc sektorowi gazu ziemnego, a od 2012 r. sektorowi telekomunikacyjnemu.

Pomoc, która nie została zakwalifikowana do żadnej z ww. grup, wyniosła 857,1 mln PLN i stanowiła rekompensatę dla przedsiębiorców z tytułu realizacji zadań publicznych. Ponad 75\% wartości pomocy stanowiła rekompensata udzielona przez Krajową Radę Radiofonii i Telewizji jednostkom radiofonii i telewizji [Raport o pomocy... 2014, s. 25].

Rola pomocy publicznej w Polsce przed wejściem w struktury Unii Europejskiej była inna niż w krajach członkowskich o długiej tradycji wolnego rynku. Wynika to m.in. z faktu, że w ostatnich latach wsparcie publiczne w Polsce miało na celu pomoc w przekształceniu gospodarki i jej dostosowaniu do funkcjonowania w warunkach rynkowych, podczas gdy w krajach UE-15 celem pomocy publicznej było utrzymanie zdolności przedsiębiorstw do konkurowania na europejskim rynku. Pomoc publiczna w Polsce różniła się pod wieloma względami: stanowiła większy udział w PKB, była skierowana do przestarzałych, wymagających restrukturyzacji sektorów przemysłu, miała przede wszystkim postać uszczupleń budżetowych, a w wyniku niedoborów finansowych i braków instytucjonalnych rzadko przyjmowała postać dotacji dla małych i średnich przedsiębiorstw. Po wejściu Polski do UE różnice te zaczęły się zacierać. Wpływ 


\begin{tabular}{|c|c|c|c|c|c|c|c|c|c|c|c|c|c|}
\hline \multirow{2}{*}{$\stackrel{m}{\stackrel{\sim}{े}}$} & (\% & 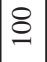 & $\mid \begin{array}{l}\hat{b} \\
\text { iे }\end{array}$ & $\hat{0}$ & $\hat{\sigma}$ & $\hat{\sigma}$ & $\vec{g}$ & $\vec{\infty}$ & ô & $\tilde{o}_{0}^{1}$ & $\stackrel{J}{0}_{0}^{ \pm}$ & I & $\infty$ \\
\hline & 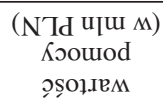 & 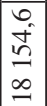 & $\begin{array}{l} \\
\dot{0} \\
\infty \\
\infty \\
+\end{array}$ & $\begin{array}{l}0 \\
\infty \\
\infty\end{array}$ & $\stackrel{m}{f}$ & $\ddot{q}$ & $\frac{a}{\hat{n}}$ & 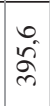 & $\stackrel{0}{=}$ & $\overrightarrow{0}$ & $\vec{i}$ & 1 & $\begin{array}{l}\infty \\
\stackrel{\infty}{n}\end{array}$ \\
\hline \multirow{2}{*}{ 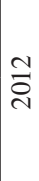 } & (\% м) f?!Zpn & 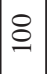 & $\begin{array}{l}m \\
\stackrel{m}{m}\end{array}$ & ते & $\stackrel{\infty}{+}$ & $\hat{\sigma}$ & $\hat{\tilde{n}}$ & $\stackrel{\Delta}{\stackrel{\Delta}{\sigma}}$ & $\hat{\sigma}$ & $\stackrel{m}{2}$ & $\tilde{\sigma}_{0}$ & I & $\stackrel{m}{i}$ \\
\hline & 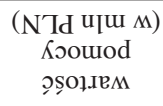 & 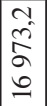 & \begin{tabular}{|l|} 
\\
$\tilde{\tilde{I}}$ \\
$\infty$ \\
$i$ \\
$i n$
\end{tabular} & $\begin{array}{l}\infty \\
\infty \\
\stackrel{0}{\beth}\end{array}$ & 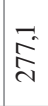 & ñ & $\vec{a}$ & 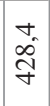 & $\frac{1}{\mathfrak{9}}$ & $\stackrel{\text { }}{\Xi}$ & $\stackrel{\infty}{0}$ & 1 & $\begin{array}{l}0 \\
\text { i } \\
n\end{array}$ \\
\hline \multirow{2}{*}{$\overline{\bar{i}}$} & (\% M) ł'!zpn & 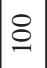 & $\frac{N}{m}$ & $\sigma_{\sigma}$ & $\stackrel{2}{2}$ & $\hat{\sigma}$ & $\begin{array}{l}0 \\
0 \\
i n\end{array}$ & $\begin{array}{l}\infty \\
\stackrel{f}{f}\end{array}$ & $\overrightarrow{0}$ & $\stackrel{\infty}{0}$ & $\because$ & 1 & $\stackrel{\Rightarrow}{\Rightarrow}$ \\
\hline & 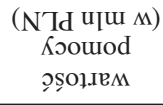 & $\begin{array}{l}\vec{n} \\
2 \\
=\end{array}$ & $\begin{array}{l}0 \\
\text { i } \\
\delta \\
0 \\
i n\end{array}$ & 志 & $\begin{array}{l}\hat{\partial} \\
\hat{\infty} \\
0\end{array}$ & $\vec{\infty}$ & $\begin{array}{l}m \\
3 \\
8 \\
\infty \\
i\end{array}$ & $\frac{2}{2}$ & $\stackrel{m}{m}$ & $\begin{array}{l}1 \\
b \\
\dot{y}\end{array}$ & $\begin{array}{l}\infty \\
\stackrel{\text { iे }}{2}\end{array}$ & 1 & ڤू \\
\hline \multirow{2}{*}{$\stackrel{\circ}{\circ}$} & (\% м) ł!zpn & 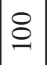 & $\begin{array}{l}2 \\
\stackrel{2}{2}\end{array}$ & $\begin{array}{l}m \\
\infty\end{array}$ & $\hat{\tilde{v}}$ & I & $\begin{array}{l}\stackrel{\vec{f}}{f} \\
\end{array}$ & $\stackrel{r}{2}$ & $\hat{\text { iे }}$ & $\hat{0}$ & $\stackrel{0}{0}$ & $\overrightarrow{0}$ & $\stackrel{0}{m}$ \\
\hline &  & \begin{tabular}{|c|}
$n$ \\
$n$ \\
$\hat{n}$ \\
$\bar{N}$ \\
\end{tabular} & \begin{tabular}{|l|}
$\vec{n}$ \\
$\widehat{\pi}$ \\
\end{tabular} & $\frac{\hat{n}}{\sqrt[n]{n}}$ & 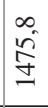 & $\begin{array}{l}\stackrel{+}{0} \\
\stackrel{0}{0}\end{array}$ & $\begin{array}{l}n \\
\\
\hat{2} \\
\end{array}$ & $\hat{\sigma}$ & 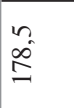 & f & $\begin{array}{l}n \\
\stackrel{n}{d}\end{array}$ & $\vec{n}$ & तु \\
\hline \multirow{2}{*}{ 总 } & (\% м) f?!Zpn &  & $\begin{array}{l}\dot{m} \\
\dot{m}\end{array}$ & ?. & $\begin{array}{l}0 \\
\text { in }\end{array}$ & $\ddot{0}$ & $\begin{array}{l}0 \\
i \\
i n\end{array}$ & $\begin{array}{l}n \\
\mathfrak{i}\end{array}$ & $\stackrel{t}{0}$ & $\tilde{n}$ & 1 & $\overrightarrow{0}$ & 1 \\
\hline & 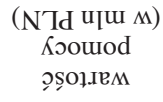 & $\mid \begin{array}{l}1 \\
\hat{2} \\
0 \\
0 \\
0 \\
0\end{array}$ & $\mid \begin{array}{c}n \\
\tilde{b} \\
i \\
i n\end{array}$ & vं & $\begin{array}{l}m \\
\cdots \\
n \\
n\end{array}$ & $\begin{array}{l}n \\
\infty \\
\infty \\
i\end{array}$ & $\vec{a}$ & $\frac{0}{i}$ & $\hat{\vec{i}}$ & $\begin{array}{l}\vec{v} \\
\stackrel{i}{g}\end{array}$ & 1 & $\stackrel{\sim}{*}$ & 1 \\
\hline \multirow{2}{*}{$\begin{array}{l}\text { 离 } \\
\stackrel{8}{8}\end{array}$} &  &  & $\hat{\tilde{y}}$ & n. & $\begin{array}{l}2 \\
\infty \\
\infty\end{array}$ & $\sigma^{+}$ & $\overrightarrow{8}$ & $\stackrel{n}{\sim}$ & 1 & $\stackrel{+}{0}$ & 1 & 1 & 1 \\
\hline &  & $\begin{array}{l}\hat{\vec{\lambda}} \\
\hat{\tilde{n}} \\
=\end{array}$ & $\begin{array}{l}n \\
\frac{2}{2} \\
\frac{a}{q}\end{array}$ & $\begin{array}{l}0 \\
\stackrel{2}{I}\end{array}$ & $\begin{array}{l}0 \\
0 \\
8 \\
\infty\end{array}$ & $\begin{array}{l}m \\
3 \\
8 \\
+\end{array}$ & $\begin{array}{l}n \\
\tilde{a} \\
2 \\
\grave{i}\end{array}$ & $\begin{array}{l}\infty \\
0 \\
\dot{d} \\
0\end{array}$ & 1 & $\frac{N}{i}$ & 1 & 1 & 1 \\
\hline \multirow{2}{*}{ 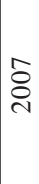 } & $(\%$ м) ұ૯!Zpn & 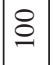 & $\begin{array}{l}n \\
2 \\
2\end{array}$ & m & 3 & : & $\begin{array}{l}\dot{\theta} \\
\text { to }\end{array}$ & $\frac{1}{2}$ & 1 & 3 & 1 & I & 1 \\
\hline & 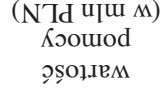 &  & $\frac{n}{\stackrel{n}{n}}$ & $\overrightarrow{0}$ & $\vec{\infty}$ & $\begin{array}{l}\infty \\
\dot{1} \\
\hat{b}\end{array}$ & $\begin{array}{l}\dot{\theta} \\
\dot{0} \\
\stackrel{i}{0}\end{array}$ & 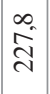 & 1 & $\begin{array}{l}\infty \\
\infty \\
\infty \\
\infty\end{array}$ & 1 & 1 & 1 \\
\hline & 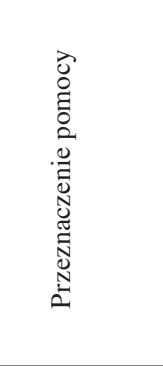 & 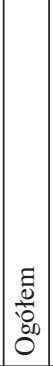 & 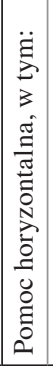 & 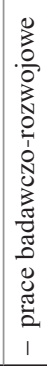 & 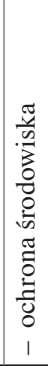 & 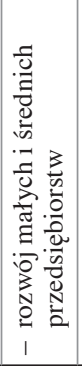 & 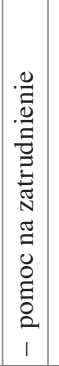 & 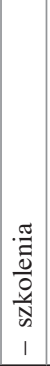 & 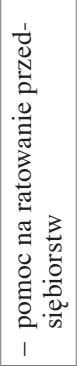 & 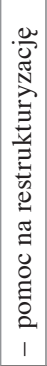 &  &  &  \\
\hline
\end{tabular}


Pomoc publiczna dla przedsiębiorstw w Polsce...

\begin{tabular}{|c|c|c|c|c|c|c|c|c|c|c|c|c|c|c|c|c|}
\hline \multirow{2}{*}{$\stackrel{m}{s}$} & $(\%$ M ) ұе!zpn & $\sigma_{0}^{\circ}$ & $=$ & 1 & ஸֶ. & 1 & $\overrightarrow{ \pm}$ & $\frac{n}{n}$ & $\stackrel{+}{i}$ & $\ddot{0}$ & $\overrightarrow{\vec{\lambda}}$ & $\vec{i}$ & बे & $\stackrel{\circ}{f}$ & $\exists$ & \\
\hline & 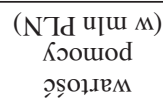 & to & $\begin{array}{l}\overrightarrow{+} \\
\stackrel{\infty}{+}\end{array}$ & 1 & $\begin{array}{l}0 \\
0 \\
0 \\
0 \\
0\end{array}$ & 1 & $\begin{array}{l}a \\
y\end{array}$ & $\begin{array}{l}m \\
\stackrel{n}{0} \\
n \\
n\end{array}$ & ה & $\frac{\hat{j}}{\mathrm{~m}}$ & ๙ૂ. & $\begin{array}{l}\overrightarrow{\tilde{n}} \\
\dot{y} \\
\sigma\end{array}$ & $\begin{array}{l}n \\
\stackrel{2}{a} \\
\infty\end{array}$ & $\begin{array}{l}\hat{\sigma} \\
\dot{\infty} \\
\infty\end{array}$ & 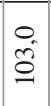 & I \\
\hline \multirow{2}{*}{ है } & $(\%$ м) fe!zpn & $\ddot{0}$ & $\hat{i}$ & $\overrightarrow{0}$ & $\stackrel{0}{=}$ & 1 & $\begin{array}{l}0 \\
\vec{\lambda}\end{array}$ & $\begin{array}{l}\infty \\
\mathcal{f}\end{array}$ & $\vec{f}$ & ?ִ & $\stackrel{r}{n}$ & $\hat{\vec{q}}$ & $\begin{array}{l}\stackrel{2}{\infty} \\
\infty\end{array}$ & $\stackrel{+}{+}$ & tó & \\
\hline & 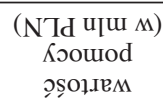 & 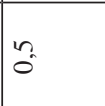 & $\begin{array}{l}\infty \\
\dot{m} \\
\stackrel{+}{2}\end{array}$ & $\theta_{0}^{\circ}$ & $\begin{array}{l}7 \\
\ddot{b} \\
\infty \\
-\end{array}$ & 1 & $\begin{array}{l}\infty \\
\tilde{c} \\
\delta \\
q\end{array}$ & ふू- & iे & $\begin{array}{l}\infty \\
\hat{\delta} \\
\tilde{m}\end{array}$ & $\begin{array}{l}0 \\
\dot{\delta} \\
\infty\end{array}$ & $\mid \begin{array}{c}a \\
\hat{y} \\
\bar{y} \\
\infty\end{array}$ & 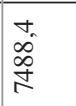 & $\frac{n}{m}$ & $\hat{s}$ & I \\
\hline \multirow[b]{2}{*}{ ฮ } & $(\%$ м) łе!̨рn & $\overrightarrow{0}$ & $\vec{f}$ & $\overrightarrow{0}$ & $\hat{\sigma}$ & 1 & $\stackrel{+}{=}$ & $\overrightarrow{0}$ & $\vec{f}$ & $\overbrace{0}$ & 1 & $\begin{array}{l}\infty \\
\hat{m} \\
\end{array}$ & $\frac{\dot{\sigma}}{\infty}$ & $\begin{array}{l}\infty \\
0\end{array}$ & $\hat{n}$ & I \\
\hline & 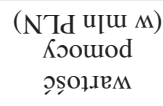 & $\stackrel{0}{0}$ & $\begin{array}{l}m \\
\vec{n} \\
\tilde{v}\end{array}$ & $\infty$ & $\begin{array}{l}a \\
\infty \\
\infty \\
\infty \\
\infty\end{array}$ & 1 & $\begin{array}{l}0 \\
0 \\
\dot{q} \\
q\end{array}$ & m.? & છे & $\begin{array}{l}\vec{\infty} \\
\infty \\
i n\end{array}$ & 1 & $\mid \begin{array}{l}0 \\
8 \\
2 \\
6 \\
6\end{array}$ & ñ & \begin{tabular}{l}
$n$ \\
fo \\
\multirow{f}{*}{}
\end{tabular} & $\begin{array}{l}n \\
n \\
\infty \\
m\end{array}$ & I \\
\hline \multirow[b]{2}{*}{ ๙ุ } & $(\%$ м) ұе!zpn & 1 & $m$ & ñ & $\mathscr{0}_{0}^{0}$ & 1 & $\hat{\tilde{N}}$ & $\begin{array}{l}n \\
\infty \\
\infty\end{array}$ & $\bar{m}$ & ले & 1 & $\begin{array}{l}n \\
n \\
i n\end{array}$ & $\begin{array}{l}0 \\
8\end{array}$ & ?n & $\begin{array}{l}0 \\
i\end{array}$ & 1 \\
\hline & 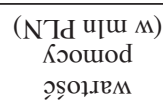 & 1 & $\begin{array}{l}\infty \\
\stackrel{0}{0} \\
\stackrel{\leftrightarrow}{0}\end{array}$ & $\hat{\varrho}$ & $\begin{array}{l}0 \\
\infty \\
\infty \\
\infty \\
\infty\end{array}$ & 1 & 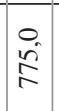 & 总 & 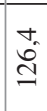 & $\underset{\infty}{\infty}$ & 1 & 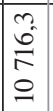 & 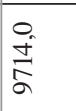 & $\stackrel{+}{\stackrel{t}{n}}$ & 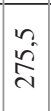 & 1 \\
\hline \multirow{2}{*}{ Әू } & $(\%$ M $)$ ұе!zpn & 1 & 1 & $\gamma$ & 年 & 1 & $\begin{array}{l}m \\
\Xi \\
\Xi\end{array}$ & & $\hat{n}$ & 1 & I & \begin{tabular}{|c|}
\multirow{2}{*}{} \\
$\infty$ \\
$\infty$ \\
+
\end{tabular} & $\begin{array}{l}\infty \\
\infty \\
\infty\end{array}$ & $n$ & $\sqrt[n]{2}$ & ה̃ \\
\hline & 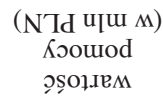 & 1 & 1 & $n$ & $\begin{array}{l}\infty \\
0 \\
\overrightarrow{0} \\
0 \\
i \\
i\end{array}$ & 1 & $\underset{m}{m}$ & $\frac{a}{\hat{\pi}}$ & $\begin{array}{l}0 \\
\text { in } \\
\text { n. }\end{array}$ & 1 & 1 & 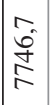 & 命 & $\frac{\hat{\imath}}{\hat{\imath}}$ & $\begin{array}{l}+ \\
\infty \\
n \\
n\end{array}$ & ठे. \\
\hline \multirow[b]{2}{*}{ 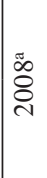 } & $(\%$ м) fe!zpn & 1 & $\ddot{0}$ & $\mathrm{~N}$ & $\frac{\vec{\lambda}}{\vec{v}}$ & 1 & $\begin{array}{l}\tilde{n} \\
\tilde{n}\end{array}$ & बे. & $\frac{m}{n}$ & 1 & 1 & $\vec{m}$ & $\hat{\alpha}$ & $\overrightarrow{0}$ & 3 & $\overbrace{0}^{n}$ \\
\hline & 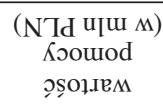 & 1 & 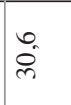 & aे & \begin{tabular}{l}
$n$ \\
\multirow{2}{*}{} \\
$\tilde{\sim}$
\end{tabular} & 1 & $\begin{array}{l}+ \\
\infty \\
\infty \\
n\end{array}$ & î & $\begin{array}{l}+ \\
\infty \\
\infty\end{array}$ & 1 & 1 & \begin{tabular}{|l|}
$\infty$ \\
$\infty$ \\
$\tilde{o}$ \\
$\sigma$ \\
\end{tabular} & 辛 & in & $\vec{r}$ & กै \\
\hline & $(\%$ M $)$ ұе!zpn & 1 & $\hat{0}^{2}$ & 3 & $a^{m}$ & $\hat{\varrho}$ & $\vec{\infty}$ & 1 & 1 & 1 & 1 & 守 & $\stackrel{n}{\infty}$ & $\widehat{0}$ & $\begin{array}{l}\infty \\
i \\
i\end{array}$ & 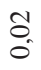 \\
\hline & 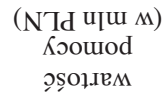 & 1 & $\infty$ & 2 & $\mid \begin{array}{l}n \\
\infty \\
\dot{f}\end{array}$ & के & बे & 1 & 1 & 1 & 1 & 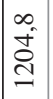 & 离 & $\stackrel{0}{\stackrel{i}{0}}$ & ले & กै \\
\hline & 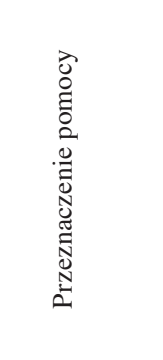 & 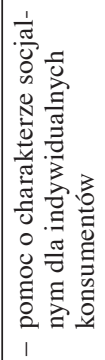 & 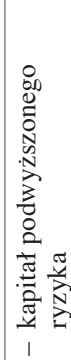 & 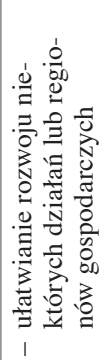 & 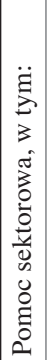 & 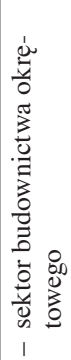 & 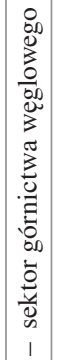 & 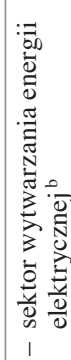 & 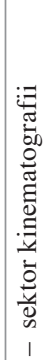 & 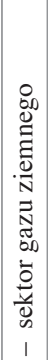 & 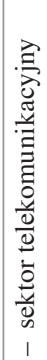 & 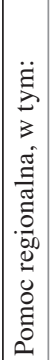 & 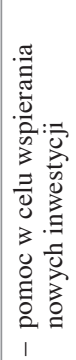 & 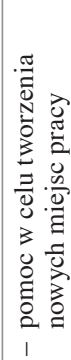 & 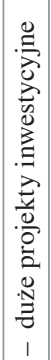 & 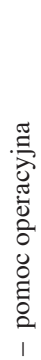 \\
\hline
\end{tabular}




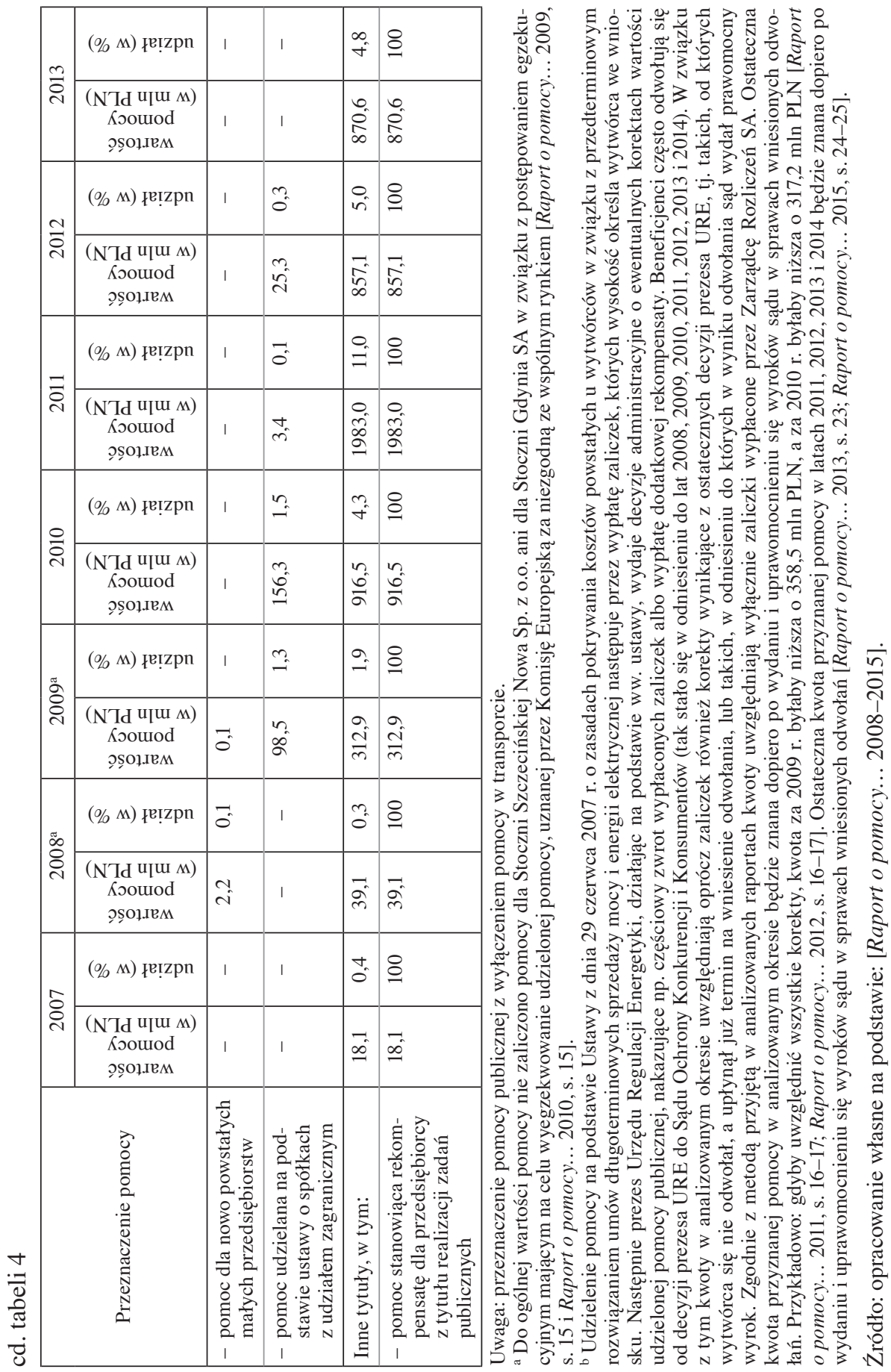


na to miała m.in. postępująca prywatyzacja przedsiębiorstw, wzrost konkurencyjności gospodarki krajowej i pełniejsze wykształcenie się mechanizmów rynkowych. Ponadto przyczynkiem do poprawy sytuacji było przejęcie kompetencji kontroli i nadzoru nad świadczeniem pomocy publicznej przez Komisję Europejską. Fakt ten spowodował, że zalecenia i postanowienia Unii Europejskiej były szybciej egzekwowane i rygorystycznie przestrzegane [Kogut-Jaworska 2010, s. 539-546].

\subsection{Wpływ pomocy publicznej na konkurencje}

Jak wcześniej wspomniano, pomoc publiczna to przysporzenie korzyści finansowych dokonywane przez państwo członkowskie w jakiejkolwiek formie, które narusza lub grozi naruszeniem konkurencji przez uprzywilejowanie niektórych przedsiębiorstw lub produkcji niektórych wyrobów, w zakresie, w jakim wpływa ono negatywnie na wymianę handlową pomiędzy państwami członkowskimi [Raport o pomocy... 2011, s. 53-55]. Z doświadczeń Urzędu Ochrony Konkurencji i Konsumentów oraz materiałów publikowanych przez Komisję Europejską wynika, że o stopniu wpływu pomocy publicznej na konkurencję decydują następujące czynniki:

- przeznaczenie pomocy. Pomoc sektorowa i pomoc na restrukturyzację stanowią potencjalnie największe zagrożenie naruszenia konkurencji. Pomoc taka stanowi zazwyczaj doraźną reakcję państwa na problemy poszczególnych podmiotów bez względu na przyczyny ich powstania, np. niegospodarność, błędy w zarządzaniu. Jako pomoc o mniej niekorzystnym wpływie na konkurencję należy wymienić pomoc horyzontalną, np. pomoc na badania i rozwój, na zatrudnienie, na ochronę środowiska itp. Pomoc taka nie jest ograniczona do określonych sektorów, a jej głównym zadaniem jest wsparcie realizacji określonego celu społeczno-gospodarczego, np. zmniejszenie bezrobocia. Jego osiągnięcie kompensuje ewentualne negatywne skutki wynikające z niekorzystnego wpływu udzielanej pomocy na konkurencję;

- wielkość beneficjenta. Im większy jest beneficjent pomocy, tym większy jego udział w rynku i silniejsza pozycja konkurencyjna. Pomoc publiczna udzielana dużym podmiotom dodatkowo wzmacnia ich pozycję, przez co ogranicza lub eliminuje istniejącą konkurencję lub też utrudnia jej powstanie;

- wartość pomocy. Ze względu na to, że pomoc publiczna negatywnie wpływa na konkurencję, można przyjąć, że im większa wartość pomocy, tym większy jej negatywny wpływ;

- sektor, w którym prowadzi działalność gospodarczą beneficjent pomocy. Poszczególne sektory działalności gospodarczej różnią się od siebie pod względem struktury, tj. liczbą działających podmiotów, ich wielkością, udziałem 
w rynku, stopniem wykorzystania mocy produkcyjnych, nasileniem konkurencji itp. W zależności od struktury danego sektora pomoc udzielona podmiotom w nim działającym może wywierać mniejszy lub większy wpływ na konkurencję. Przykładowo w sektorze transportu drogowego działa dużo małych podmiotów i występuje tzw. nadwyżka mocy produkcyjnych. W takiej sytuacji nawet niewielka wartość pomocy publicznej pozwala poprawić pozycję konkurencyjną beneficjenta w stosunku do jego konkurentów.

\section{Podsumowanie}

Analizując dane dotyczące skali i wykorzystania pomocy publicznej przez polskie przedsiębiorstwa w latach 2007-2013, można zauważyć, że [Raport o pomocy... 2014, s. 72-73; Raport o pomocy... 2015, s. 72]:

- od 2007 r. obserwujemy wahania wartości udzielanej pomocy publicznej. Wskaźnik wartości pomocy w PKB pokazuje, że w 2014 r. nastąpiło przerwanie trwającej od 2010 r. tendencji spadkowej;

- w latach 2007-2013 najczęściej udzielano pomocy w formach należących do grupy A (dotacje i ulgi podatkowe), których udział w ostatnich pięciu latach przekraczał poziom $85 \%$;

- w badanym okresie najwyższa była wartość pomocy regionalnej;

- w 2013 r. odnotowano spadek wartości pomocy horyzontalnej w porównaniu z rokiem poprzednim oraz spadek jej udziału w ogólnej wartości pomocy;

- wartość pomocy, która nie została zakwalifikowana do żadnej z ww. grup przeznaczenia, utrzymywała się $\mathrm{w}$ analizowanych latach na podobnym poziomie i była to pomoc stanowiąca rekompensatę dla przedsiębiorców z tytułu realizacji zadań publicznych;

- Państwowy Fundusz Rehabilitacji Osób Niepełnosprawnych, Polska Agencja Rozwoju Przedsiębiorczości, marszałkowie województw, organy podatkowe oraz minister gospodarki udzielili łącznie ponad $65 \%$ ogólnej wartości pomocy (z wyłączeniem pomocy udzielonej w sektorze transportu);

- pomoc o najwyższej wartości trafiła w 2013 r. do przedsiębiorstw prywatnych;

- w 2013 r., podobnie jak w latach poprzednich, pomoc publiczną o najwyższej wartości skierowano do dużych przedsiębiorstw;

- w 2013 r. istniało 128 programów pomocowych, w ramach których można było udzielać pomocy;

- w 2013 r. nie udzielono pomocy na podstawie 40 programów pomocowych. Około $1 / 3$ tej liczby stanowią programy zakładające pomoc na realizację dużych inwestycji, w przypadku których wybór beneficjenta pomocy może być procesem 
długotrwałym, a ok. 1/5 - uchwały gminne z lat 2006-2007, na podstawie których gminy mogą udzielać pomocy, i choć z takiej możliwości w 2013 r. nie skorzystały, deklarują, że chcą pozostawić sobie taką możliwość na przyszłość. Pewna liczba programów (ok. 10\%) to programy, które z założenia mają być wykorzystywane tylko w przypadku wystąpienia określonych zdarzeń, które w 2013 r. nie wystąpiły. Przykładem są programy wspierania banków.

Podsumowując, główną grupę beneficjentów pomocy horyzontalnej stanowią przedsiębiorstwa. Pomoc ta stanowi ważne ogniwo pomocy publicznej w Polsce, co jednocześnie zgodne jest z zaleceniami Rady Europejskiej.

\section{Literatura}

Kierunki udzielania pomocy publicznej w latach 2007-2013 [2008], Ministerstwo Gospodarki, Warszawa, maj.

Kogut-Jaworska M. [2010], Znaczenie dotacji i subsydiów podatkowych w systemie pomocy publicznej w Polsce - wybrane zagadnienia, Zeszyty Naukowe Uniwersytetu Ekonomicznego w Poznaniu, nr 141, Poznań.

Komunikat Komisji w sprawie zmiany metody ustalania stóp referencyjnych i dyskontowych, Dz.Urz. UE C 14 z 19 stycznia 2008 r.

Krzemińska U. [2008], Zasady pomocy publicznej i depozytów w przepisach unijnych i polskich, „Prawo i Podatki Unii Europejskiej w Praktyce”, nr 12.

Marquardt P. [2007], Pomoc publiczna dla małych i średnich przedsiębiorców, LexisNexis, Warszawa.

Raport o pomocy publicznej w Polsce udzielonej przedsiębiorcom w 2007 roku [2008], Urząd Ochrony Konkurencji i Konsumentów, Warszawa, listopad.

Raport o pomocy publicznej w Polsce udzielonej przedsiębiorcom w 2008 roku [2009], Urząd Ochrony Konkurencji i Konsumentów, Warszawa, grudzień.

Raport o pomocy publicznej w Polsce udzielonej przedsiębiorcom w 2009 roku [2010], Urząd Ochrony Konkurencji i Konsumentów, Warszawa, grudzień.

Raport o pomocy publicznej w Polsce udzielonej przedsiębiorcom w 2010 roku [2011], Urząd Ochrony Konkurencji i Konsumentów, Warszawa, grudzień.

Raport o pomocy publicznej w Polsce udzielonej przedsiębiorcom w 2011 roku [2012], Urząd Ochrony Konkurencji i Konsumentów, Warszawa, grudzień.

Raport o pomocy publicznej w Polsce udzielonej przedsiębiorcom w 2012 roku [2013], Urząd Ochrony Konkurencji i Konsumentów, Warszawa, wrzesień.

Raport o pomocy publicznej w Polsce udzielonej przedsiębiorcom w 2013 roku [2014], Urząd Ochrony Konkurencji i Konsumentów, Warszawa, październik.

Raport o pomocy publicznej w Polsce udzielonej przedsiębiorcom w 2014 roku [2015], Urząd Ochrony Konkurencji i Konsumentów, Warszawa, grudzień.

Rozporządzenie Komisji (WE) nr 800/2008 z dnia 6 sierpnia 2008 r. uznające niektóre rodzaje pomocy za zgodne ze wspólnym rynkiem w zastosowaniu art. 87 i 88 Traktatu (ogólne rozporządzenie w sprawie wyłączeń blokowych), Dz.Urz. UE L 214/3 z 9 sierpnia $2008 \mathrm{r}$.

Rozporządzenie Rady Ministrów z dnia 13 października 2006 r. w sprawie ustalenia mapy pomocy regionalnej, Dz.U. nr 190 poz. 1402. 
Traktat o funkcjonowaniu Unii Europejskiej, Dz.Urz. UE C 326 z 26 października 2012 r. Traktat ustanawiający Wspólnotę Europejską, Dz.Urz. UE C 321 E/1 z 29 grudnia 2006 r. Traktat z Lizbony zmieniający Traktat o Unii Europejskiej i Traktat ustanawiający Wspólnotę Europejską, sporządzony w Lizbonie dnia 13 grudnia 2007 r., Dz.Urz. UE C 306 z 17 grudnia $2007 \mathrm{r}$.

Układ Europejski ustanawiający stowarzyszenie między Rzecząpospolitą Polską, z jednej strony, a Wspólnotami Europejskimi i ich Państwami Członkowskimi, z drugiej strony, sporządzony w Brukseli dnia 16 grudnia 1991 r., Dz.U. 1994 nr 11 poz. 38.

Ustawa z dnia 30 kwietnia 2004 r. o postępowaniu w sprawach dotyczących pomocy publicznej, tekst jedn. Dz.U. z 2007 r. nr 59 poz.404 ze zm.

Ustawa z dnia 28 lipca 2005 r. o zmianie ustawy o autostradach płatnych oraz o Krajowym Funduszu Drogowym oraz ustawy o transporcie drogowym, Dz.U. nr 155 poz. 1297.

Ustawa z dnia 29 czerwca 2007 r. o zasadach pokrywania kosztów powstałych u wytwórców w związku z przedterminowym rozwiązaniem umów długoterminowych sprzedaży mocy i energii elektrycznej, Dz.U. nr 130 poz. 905.

Ustawa z dnia 8 stycznia 2010 r. o zmianie ustawy o postępowaniu w sprawach dotyczących pomocy publicznej, tekst jedn. Dz.U. nr 18 poz. 99.

\section{Public Support for Enterprises in Poland in 2007-2013}

(Abstract)

State aid in Poland is gradually beginning to take on the character of aid for stimulating social and economic development, one of the fundamental objectives of the renewed Lisbon Strategy. The article discusses state aid granted in Poland in the years 2007-2013. Analysis of the data for the period leads to the following conclusions: the beneficiaries of approximately half of the aid were large enterprises; the most frequently used aid instruments were grants (group A1); regional aid was awarded the most. After Poland's accession to the EU, its differences from member states began to fade, thanks in part to the EC's control and supervision of the provision of aid.

Keywords: state aid, enterprise, European Union, EU funds. 